\title{
Synthesis of Two Testosterone Derivatives and their Theoretical Evaluation as Serotonin Reuptake Transporter Inhibitors
}

\author{
Lauro Figueroa-Valverde 1,*(D), Magdalena Alvarez-Ramirez 2(D), Marcela Rosas-Nexticapa 2(D), \\ Francisco Díaz-Cedillo ${ }^{3}{ }^{\mathbb{D}}$, Maria López-Ramos ${ }^{1 \mathbb{1}}$, Maria Virginia Mateu-Armad ${ }^{2}{ }^{\mathbb{D}}$, Tomas Lopez- \\ Gutierrez $^{1 \text { (D) }}$, Regina Cauich-Carrillo ${ }^{1}$ (D) \\ 1 Laboratory of Pharmaco-Chemistry, Faculty of Chemical Biological Sciences, University Autonomous of Campeche, Av. \\ Humberto Lanz Cárdenas S/N, Colonia Ex Hacienda Kalá, C.P. 24085, Campeche, Mexico \\ 2 Escuela Nacional de Ciencias Biológicas del Instituto Politécnico Nacional. Prol. Carpio y Plan de Ayala s/n Col. Santo \\ Tomas, D.F. C.P. 11340, México \\ 3 Facultad de Nutrición, Universidad Veracruzana, Médicos y Odontologos s/n C.P. 91010, Unidad del Bosque Xalapa \\ Veracruz, México \\ * Correspondence:lauro_1999@yahoo.com; lfiguero@uacam.mx;
}

Scopus Author ID 55995915500

Received: 7.12.2020; Revised: 2.01.2021; Accepted: 3.01.2021; Published: 6.01.2021

\begin{abstract}
This investigation aimed to synthesize two testosterone derivatives (4 and 7) from either testosterone 3-oxime or testosterone 3-(O-carboxymethyl)oxime. The chemical structure of the compounds was determined using nuclear magnetic resonance spectra. Besides, testosterone derivatives' theoretical activity on serotonin transporter (5i6z protein) was evaluated using fluoxetine as a control in a Docking model. The results showed a higher interaction of both compounds 4 and 7 with a $5 \mathrm{i} 6 \mathrm{z}$ protein surface compared with fluoxetine. In conclusion, it's noteworthy that reagents used in this investigation no require special conditions. Also, the theoretical study showed that either compounds 4 or 7 could be good serotonin transporter inhibitors.
\end{abstract}

Keywords: testosterone; synthesis; serotonin; protein.

(C) 2020 by the authors. This article is an open-access article distributed under the terms and conditions of the Creative Commons Attribution (CC BY) license (https://creativecommons.org/licenses/by/4.0/).

\section{Introduction}

Biogenic amine reuptake inhibitors have been used as an antidepressant; for example, fluoxetine (serotonin reuptake inhibitor selective) [1, 2], imipramine (noradrenaline and reuptake inhibitor non-selective), vanoxerine (dopamine reuptake inhibitor selective) [4], moclobemide (monoamine oxidase inhibitor) [5]; however, some of these drugs can produce some adverse effects such as tiredness [6], psychomotor retardation [7], increases body weight [8] and others. In the search for some alternative therapeutic, some drugs have been developed for the treatment of depression as amine reuptake inhibitors; in this way, the hydroxynorketamine was prepared from 1-Chloro-2-cyclohex-1-enyl-benzene [9]. In addition, other studies display the preparation of paroxetine via reaction of arene-diazonium tetrafluoroborate salt with an ester derivative [10]. Besides, a study displayed an indole analog reaction with $\mathrm{N}$-Boc-piperidinone to form an indol-isoquinoline derivative [11]. Other data showed cyclic ketoesters' reaction with arylboronates to the synthesis of some phenyltropane analogs [12]. In addition, a report displayed the preparation of several cyclopropane analogs 
from sulfonium-ylide [13]. Another study showed the synthesis of an imipramine derivative from dihydroxymethyl imipramine and palladium [14]. All these reports use different protocols that require several reagents that require special conditions such as differences in the heat and $\mathrm{pH}$. Analyzing these data, in this investigation, two testosterone analogs were prepared using some chemical reactions. Besides, the theoretical interaction of two testosterone derivatives on reuptake serotonin transporter was evaluated.

\section{Materials and Methods}

\subsection{General.}

All reagents used in this research were acquired from Sigma-Aldrich Co., Ltd. The melting point for compounds was evaluated on an Electrothermal (900 model). Infrared spectra (IR) were evaluated with a Thermo Scientific iSOFT-IR spectrometer. ${ }^{1} \mathrm{H}$ and ${ }^{13} \mathrm{C}$ NMR spectra were recorded using a Varian VXR300/5 FT NMR spectrometer at $300 \mathrm{MHz}$ in $\mathrm{CDCl}_{3}$ using TMS as an internal standard. EIMS spectra were obtained with a Finnigan Trace Gas Chromatography Polaris Q-Spectrometer. Elementary analysis data were acquired from a Perkin Elmer Ser. II CHNS/02400 elemental analyzer.

\subsubsection{Synthesis.}

\section{(3E,10R,13S,17S)-3-(2-hydroxyethoxyimino)-10,13-dimethyl-1,2,6,7,8,9,11,12,14,15,16, 17-dodecahydrocyclopenta[a]phenanthren-17-ol (2)}

A solution of testosterone 3-(O-carboxymethyl)oxime (200 $\mathrm{mg}, 0.55 \mathrm{mmol})$, sodium borohydride ( $40 \mathrm{mg}, 0.63 \mathrm{mmol}$ ) in ethanol was stirring for $72 \mathrm{~h}$ at room temperature. Then, the solvent was evaporated under reduced pressure and following the product was purified via crystallization using the methanol:hexane:agua (3:1:1) system; yielding 54\% of product; m.p. 186-188 ${ }^{\circ} \mathrm{C}$; IR $\left(V_{\max }, \mathrm{cm}^{-1}\right)$ 3400, and 3320: ${ }^{1} \mathrm{H}$ NMR $\left(300 \mathrm{MHz}, \mathrm{CDCl}_{3}-d\right) \delta_{\mathrm{H}}: 0.82(\mathrm{~s}, 3 \mathrm{H})$, 0.96-1.02 (m, 2H), $1.04(\mathrm{~s}, 3 \mathrm{H}), 1.07-1.88(\mathrm{~m}, 12 \mathrm{H}), 2.10-3.64(\mathrm{~m}, 6 \mathrm{H}), 3.71(\mathrm{~m}, 2 \mathrm{H}), 3.95$ (broad, 2H), $4.08(\mathrm{~m}, 2 \mathrm{H}), 5.70(\mathrm{~d}, 1 \mathrm{H}, J=0.70 \mathrm{~Hz}) \mathrm{ppm} .{ }^{13} \mathrm{C} \mathrm{NMR}\left(300 \mathrm{~Hz}, \mathrm{CDCl}_{3}\right) \delta_{\mathrm{C}}: 11.10$, 17.73, 20.94, 23.34, 29.22, 30.30, 31.32, 31.42, 31.70, 35.26, 35.33, 36.50, 42.82, 50.54, 50.60, 62.92, 73.76, 80.82, 114.90, 152.41, $157.40 \mathrm{ppm}$. EI-MS m/z: 347.24. Anal. Calcd. for $\mathrm{C}_{21} \mathrm{H}_{33} \mathrm{NO}_{3}: \mathrm{C}, 72.58 ; \mathrm{H}, 9.57 ; \mathrm{N}, 4.03 ; \mathrm{O}, 13.81$. Found: $\mathrm{C}, 72.56 ; \mathrm{H}, 9.54$.

(3E,10R,13S,17S)-3-(2-hydroxyethoxyimino)-10,13-dimethyl-4-nitro-1,2,6,7,8,9,11,12, 14,15,16,17-dodecahydrocyclopenta[a]phenanthren-17-ol (3)

A solution of compound $2(200 \mathrm{mg}, 0.57 \mathrm{mmol})$, acetic anhydride $(3 \mathrm{ml})$ and nitric acid $(5 \mathrm{ml})$ was stirring for $8 \mathrm{~h}$ at reflux. Then, the solvent was evaporated under reduced pressure and following the product was purified via crystallization using the methanol:agua (4:1) system; yielding 54\% of product; m.p. $146-148{ }^{\circ} \mathrm{C}$; IR $\left(V_{\max }, \mathrm{cm}^{-1}\right) 3402,3320$ and $1542:{ }^{1} \mathrm{H}$ NMR (300 MHz, $\left.\mathrm{CDCl}_{3}-d\right) \delta_{\mathrm{H}}: 0.82(\mathrm{~s}, 3 \mathrm{H}), 0.96-1.10(\mathrm{~m}, 2 \mathrm{H}), 1.14(\mathrm{~s}, 3 \mathrm{H}), 1.16-1.88(\mathrm{~m}$, $12 \mathrm{H}), 2.04-3.64(\mathrm{~m}, 6 \mathrm{H}), 3.71(\mathrm{~m}, 2 \mathrm{H}), 3.95$ (broad, $2 \mathrm{H}), 4.08(\mathrm{~m}, 2 \mathrm{H}) \mathrm{ppm} .{ }^{13} \mathrm{C}$ NMR $(300$ $\left.\mathrm{Hz}, \mathrm{CDCl}_{3}\right) \delta \mathrm{c}: 11.10,19.00,20.94,23.28,25.22,26.84,30.12,30.90,32.18,35.33,36.50$, 40.16, 42.78, 49.66, 50.60, 62.92, 73.76, 80.52, 144.76, 148.90, 150.00 ppm. EI-MS m/z: 392.23. Anal. Calcd. for $\mathrm{C}_{21} \mathrm{H}_{32} \mathrm{~N}_{2} \mathrm{O}_{5}$ : C, 64.26; H, 8.22; N, 7.14; O, 20.38. Found: C, 64.22; $\mathrm{H}, 8.20$. 
$(1 \mathrm{R}, 5 \mathrm{~S}, 6 \mathrm{~S})-1,5$-dimethyl-15,18-dioxa-19-azapentacyclo[11.9.0.02,10.05,9.014,20]docosa13,19-dien-6-ol (4)

A solution of compound $3(200 \mathrm{mg}, 0.50 \mathrm{mmol})$, potassium carbonate $(85 \mathrm{mg}, 0.6$ $\mathrm{mmol}$ ) in $5 \mathrm{ml}$ of dimethyl sulfoxide was stirring for $72 \mathrm{~h}$ at room temperature. Then, the solvent was evaporated under reduced pressure and following the product was purified via crystallization using the methanol:hexane:agua (4:1:1) system; yielding $65 \%$ of product; m.p. 222-224 ${ }^{\circ} \mathrm{C}$; IR $\left(V_{\max }, \mathrm{cm}^{-1}\right)$ 3400, 3380 and 1208: ${ }^{1} \mathrm{H}$ NMR $\left(300 \mathrm{MHz}, \mathrm{CDCl}_{3}-d\right) \delta_{\mathrm{H}}: 0.82$ (s, $3 \mathrm{H}), 0.96-1.05(\mathrm{~m}, 3 \mathrm{H}), 1.07(\mathrm{~s}, 3 \mathrm{H}), 1.10-1.96(\mathrm{~m}, 13 \mathrm{H}), 2.66-3.12(\mathrm{~m}, 3 \mathrm{H}), 3.18-3.23(\mathrm{~m}$, $2 \mathrm{H}), 3.66(\mathrm{~m}, 1 \mathrm{H}), 3.92-4.02(\mathrm{~m}, 2 \mathrm{H}), 6.22$ (broad, $1 \mathrm{H}) \mathrm{ppm} .{ }^{13} \mathrm{C} \mathrm{NMR}\left(300 \mathrm{~Hz}, \mathrm{CDCl}_{3}\right) \delta \mathrm{C}$ : $11.10,20.90,20.94,22.02,23.28,29.90,30.12$, 30.98, 31.70, 35.33, 36.50, 38.58, 42.78, 49.96, 50.60, 65.49, 70.56, 80.52, 128.55, 145.00, 161.10 ppm. EI-MS m/z: 345.23. Anal. Calcd. for $\mathrm{C}_{21} \mathrm{H}_{31} \mathrm{NO}_{3}$ : C, 73.01; H, 9.04; N, 4.05; O, 13.89. Found: C, 73.00; H, 9.02.

(10R,13S,17S)-17-hydroxy-10,13-dimethyl-4-nitro-1,2,6,7,8,9,11,12,14,15,16,17-dodecahydrocyclopenta[a]phenanthren-3-one oxime (6)

A solution of compound testosterone-3-oxime (200 $\mathrm{mg}, 0.66 \mathrm{mmol})$, acetic anhydride $(3 \mathrm{ml})$ and $5 \mathrm{ml}$ of nitric acid were stirring for $8 \mathrm{~h}$ at reflux. Then, the solvent was evaporated under reduced pressure and following the product was purified via crystallization using the methanol:agua (4:1) system; yielding 70\% of product; m.p. $222-224{ }^{\circ} \mathrm{C}$; IR $\left(V_{\max }, \mathrm{cm}^{-1}\right) 3400$, 3320 and 1540: ${ }^{1} \mathrm{H}$ NMR $\left(300 \mathrm{MHz}, \mathrm{CDCl}_{3}-d\right) \delta_{\mathrm{H}} 0.82(\mathrm{~s}, 3 \mathrm{H}), 0.96-1.10(\mathrm{~m}, 2 \mathrm{H}), 1.12(\mathrm{~s}$, $3 \mathrm{H}), 1.18-1.90(\mathrm{~m}, 12 \mathrm{H}), 2.06-3.66(\mathrm{~m}, 1 \mathrm{H}), 3.92-4.02(\mathrm{~m}, 6 \mathrm{H}), 6.94$ (broad, $2 \mathrm{H}) \mathrm{ppm} .{ }^{13} \mathrm{C}$ $\operatorname{NMR}\left(300 \mathrm{~Hz}, \mathrm{CDCl}_{3}\right) \delta_{\mathrm{C}}: 11.10,19.00,20.94,22.02,23.28,24.90,26.80,30.12,30.92,31.32$, 35.33, 36.50, 40.18, 42.78, 49.66, 50.60, 80.52, 143.96, 151.50, $156.02 \mathrm{ppm}$. EI-MS m/z: 348.20. Anal. Calcd. for $\mathrm{C}_{19} \mathrm{H}_{28} \mathrm{~N}_{2} \mathrm{O}_{4}$ : C, 65.49; H, 8.10; N, 8.04; O, 18.37. Found: C, 65.46; $\mathrm{H}, 8.08$.

\section{(2R,16S,17S)-2,17-dimethyl-7-oxa-6-azapentacyclo[10.7.0.02,9.05,8.013,17]nonadeca-5,} 8-dien-16-ol (7)

A solution of compound $6(200 \mathrm{mg}, 0.57 \mathrm{mmol})$, potassium carbonate $(85 \mathrm{mg}, 0.60$ $\mathrm{mmol}$ ) in $5 \mathrm{ml}$ of dimethyl sulfoxide were stirring for $72 \mathrm{~h}$ at room temperature. Then, the solvent was evaporated under reduced pressure and following the product was purified via crystallization using the methanol:agua (4:1) system; yielding 54\% of product; m.p. 135-137 ${ }^{\circ} \mathrm{C}$; IR $\left(V_{\max }, \mathrm{cm}^{-1}\right) 3400,3322$ and 1242: ${ }^{1} \mathrm{H}$ NMR $\left(300 \mathrm{MHz}, \mathrm{CDCl}_{3}-d\right) \delta_{\mathrm{H}}: 0.82(\mathrm{~s}, 3 \mathrm{H}), 0.96-$ $1.04(\mathrm{~m}, 3 \mathrm{H}), 1.06(\mathrm{~s}, 3 \mathrm{H}), 1.10-1.98(\mathrm{~m}, 13 \mathrm{H}), 2.60-3.66(\mathrm{~m}, 4 \mathrm{H}), 6.23(\mathrm{broad}, 1 \mathrm{H}) \mathrm{ppm} .{ }^{13} \mathrm{C}$ $\operatorname{NMR}\left(300 \mathrm{~Hz}, \mathrm{CDCl}_{3}\right) \delta \mathrm{c}: 11.10,20.22,20.94,21.60,23.28,30.12,30.92,30.16,30.22,30.90$, 35.33, 36.50, 37.42, 42.78, 50.44, 50.60, 80.52, 129.96, 142.76, $169.60 \mathrm{ppm}$. EI-MS m/z: 301.20. Anal. Calcd. for $\mathrm{C}_{19} \mathrm{H}_{27} \mathrm{NO}_{2}$ : C, 75.71; H, 9.03; N, 4.65; O, 10.62. Found: C, 75.68; H, 9.00 .

\subsection{Theoretical evaluation.}

The interaction of both compounds 4 and 7 with serotonin (5i6z) [15] transporter protein was evaluated using the DockingServer software [16]. Besides, fluoxetine (serotonin transporter inhibitor) [17] was used as a control. 


\section{Results and Discussion}

Several Biogenic amine reuptake inhibitors have been synthesized using different protocols $[9,14]$; in this research, two testosterone derivatives were synthesized from either testosterone 3-(O-carboxymethyl)oxime or 3-oxime testosterone as follows:

\subsection{Chemistry.}

\subsubsection{Reduction reaction.}

There are several reports for the reduction of carboxyl groups using several reagents such as sodium borohydride/samarium chloride [18], disiamylborane [19], borohydride [20], sodium borohydride and diborane [21], lithium borohydride [22], cyanuric chloride/sodium borohydride [23], and others. In this investigation, the carboxyl group of compound 1 was reduced in the presence of sodium borohydride to form compound 2 (Figure 1). The ${ }^{1} \mathrm{H}$ NMR spectrum from 2 display some bands signals at 0.82 and $1.04 \mathrm{ppm}$ for methyl groups; at 0.96$1.02,1.07-3.64$ and $5.70 \mathrm{ppm}$ for steroid moiety; at 3.71 and $4.08 \mathrm{ppm}$ for methylene groups linked to both hydroxyl and oxime groups; at $3.95 \mathrm{ppm}$ for hydroxyl groups. ${ }^{13} \mathrm{C}$ NMR spectra showed chemical shifts at 11.10-17.73 ppm for methyl groups; at 20.94-50.60 and 80.82$157.40 \mathrm{ppm}$ for steroid moiety; at $62.92-73.76 \mathrm{ppm}$ for methylene groups linked to both hydroxyl and oxime groups. Besides, the mass spectrum from 2 displayed a molecular ion $(\mathrm{m} / \mathrm{z})$ 347.24 .
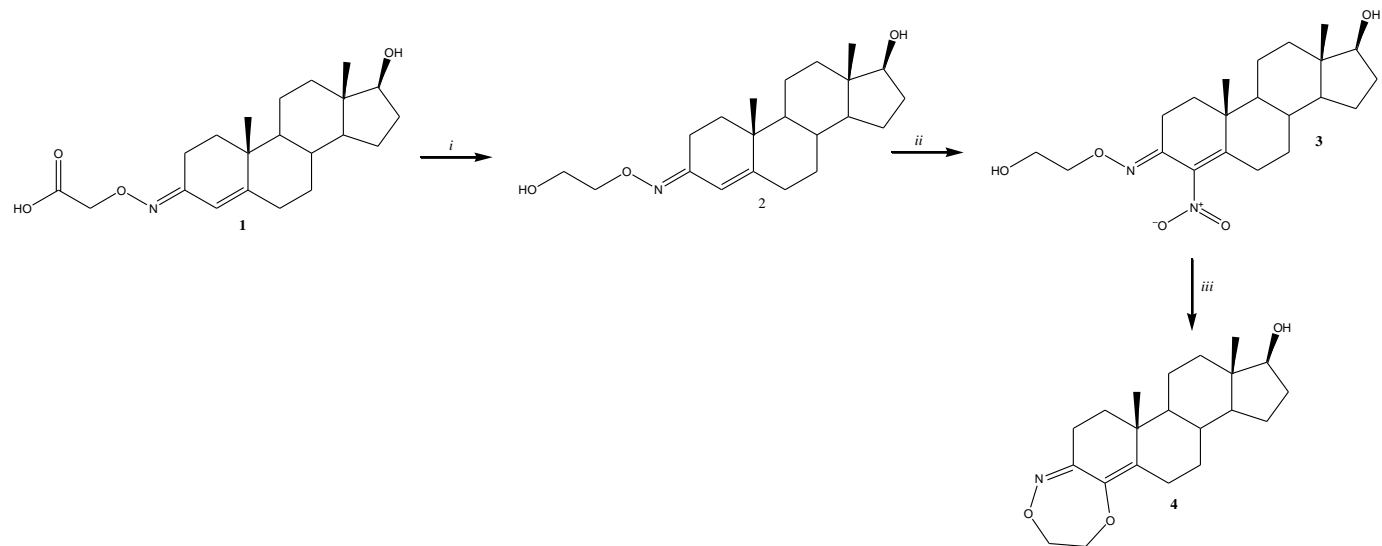

Figure 1. Synthesis of an ether-steroid derivative (4). Reagents and conditions: $i=$ sodium cyanoborohydride, room temperature, $12 \mathrm{hs;} \quad i i=$ acetic anhydride, nitric acid, reflux $8 \mathrm{~h}$; $i i i=$ potassium carbonate, dimethyl sulfoxide, room temperature, $72 \mathrm{~h}$.

\subsubsection{Synthesis of a nitro-steroid derivative.}

There are several methods for the synthesis of nitro derivatives using some reagents such as dimethyldioxirane [24], $\mathrm{NaNO}_{2}$ [25], $\mathrm{HNO}_{3}$ [26], $\mathrm{NOF}$ [27], $\mathrm{HNO}_{3} /\left(\mathrm{CH}_{3} \mathrm{CO}\right)_{2} \mathrm{O}$ [28], and others. In this investigation, 3 was prepared from compound 2, nitric acid, and anhydride acetic (Figure 1). The ${ }^{1} \mathrm{H}$ NMR spectrum from 3 showed several signals at 0.82 and $1.14 \mathrm{ppm}$ for methyl groups; at 0.96-1.10, 1.16-3.64 and $5.70 \mathrm{ppm}$ for steroid moiety; at 3.71 and 4.08 ppm for methylene groups linked to both hydroxyl and oxime groups; at $3.95 \mathrm{ppm}$ for a hydroxyl group. ${ }^{13} \mathrm{C}$ NMR spectra showed chemical shifts at $11.10-19.00 \mathrm{ppm}$ for methyl groups; at 20.94-50.60 and 80.82-150.02 ppm for steroid moiety; at 62.92-73.76 ppm for methylene groups linked to both hydroxyl and oxime groups. Besides, the mass spectrum from 3 displayed a molecular ion (m/z) 392.23. 


\subsubsection{Preparation of an ether-steroid derivative.}

Several ether analogs have been synthesized using different reagents such as $\mathrm{Ta} / \mathrm{Al}_{2} \mathrm{O}_{3}$ [29], palladium [30], tert-Butyl Nitrite [31], Ceric Ammonium Nitrate [32]. Some reports also showed the preparation of ether derivatives through the nitro group's displacement using dipolar aprotic solvents such as dimethyl sulfoxide [33]. In this way, an ether-steroid analog (4) was prepared from compound 3, dimethyl sulfoxide, and sodium carbonate (Figure 1). The ${ }^{1} \mathrm{H}$ NMR spectrum from 4 showed several signals at 0.82 and $1.07 \mathrm{ppm}$ for methyl groups; at 0.96-1.05, 1.10-3.12 and 3.66 ppm for steroid moiety; at 3.18-3.23 and 3.92-4.02 ppm for 6,7Dihydro-4H-[1,5,2]dioxazepine ring; at $6.22 \mathrm{ppm}$ for a hydroxyl group. ${ }^{13} \mathrm{C}$ NMR spectra showed chemical shifts at 11.10-20.90 ppm for methyl groups; at 20.94-50.60 and 80.52$161.10 \mathrm{ppm}$ for steroid moiety; at 65.49-70.56 ppm for 6,7-Dihydro-4H-[1,5,2] dioxazepine ring. Additionally, the mass spectrum from 4 showed a molecular ion $(\mathrm{m} / \mathrm{z}) 345.23$.

\subsubsection{Preparation of a 4-nitro-testosterone oxime.}

This stage was achieved via nitration of 3-oxime testosterone in the presence of nitric acid and anhydride acetic. The ${ }^{1} \mathrm{H}$ NMR spectrum from $\mathbf{6}$ showed several signals at 0.82 and 1.07 ppm for methyl groups; at 0.96-1.05, 1.10-3.12 and 3.66 ppm for steroid moiety; at 3.183.23 and 3.92-4.02 ppm for 6,7-Dihydro-4H-[1,5,2]dioxazepine ring; at $6.22 \mathrm{ppm}$ for a hydroxyl group. ${ }^{13} \mathrm{C}$ NMR spectra showed chemical shifts at $11.10-20.90 \mathrm{ppm}$ for methyl groups; at 20.94-50.60 and 80.52-161.10 ppm for steroid moiety; at 65.49-70.56 ppm for 6,7Dihydro-4H-[1,5,2] dioxazepine ring. Additionally, the mass spectrum from 6 displayed a molecular ion $(\mathrm{m} / \mathrm{z}) 345.23$.

\subsubsection{Synthesis of an azete-steroid derivative.}

In this investigation, an azete-steroid derivative was prepared the compound $\mathbf{7}$ from an intramolecular reaction of $\mathbf{6}$ in the presence of dimethylsulfoxide/potassium carbonate (Figure 2). The ${ }^{1} \mathrm{H}$ NMR spectrum from 7 showed several signals at 0.82 and $1.06 \mathrm{ppm}$ for methyl groups; at 0.96-1.04 and 1.10-3.66 ppm for steroid moiety; at $6.23 \mathrm{ppm}$ for a hydroxyl group. ${ }^{13} \mathrm{C}$ NMR spectra showed chemical shifts at 11.10-20.22 ppm for methyl groups; at 20.94$142.76 \mathrm{ppm}$ for steroid moiety; $169.60 \mathrm{ppm}$ for imino group. Besides, the mass spectrum from 7 displayed a molecular ion $(\mathrm{m} / \mathrm{z}) 301.20$.

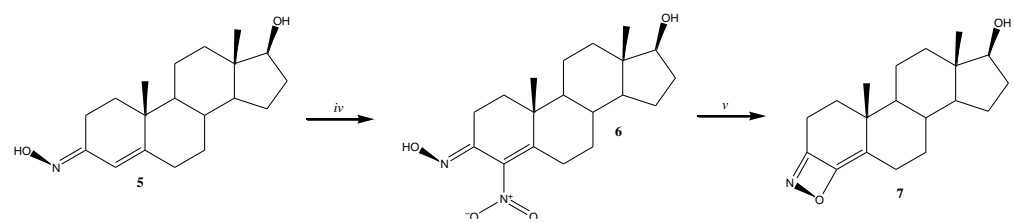

Figure 2. Synthesis of an azete-steroid derivative (7). Reagents and conditions: $\mathrm{i}=$ acetic anhydride, nitric acid, reflux $8 \mathrm{~h}$.

\subsubsection{Teorethical evaluation.}

In the literature, some studies have been used to evaluate the ligand-protein interaction of some drugs [34-36]. In this way, compounds 4 and 7 were used to determine their interaction with serotonin transporter (5i6z protein) in DockingServer software (Figures 3 and 4). 

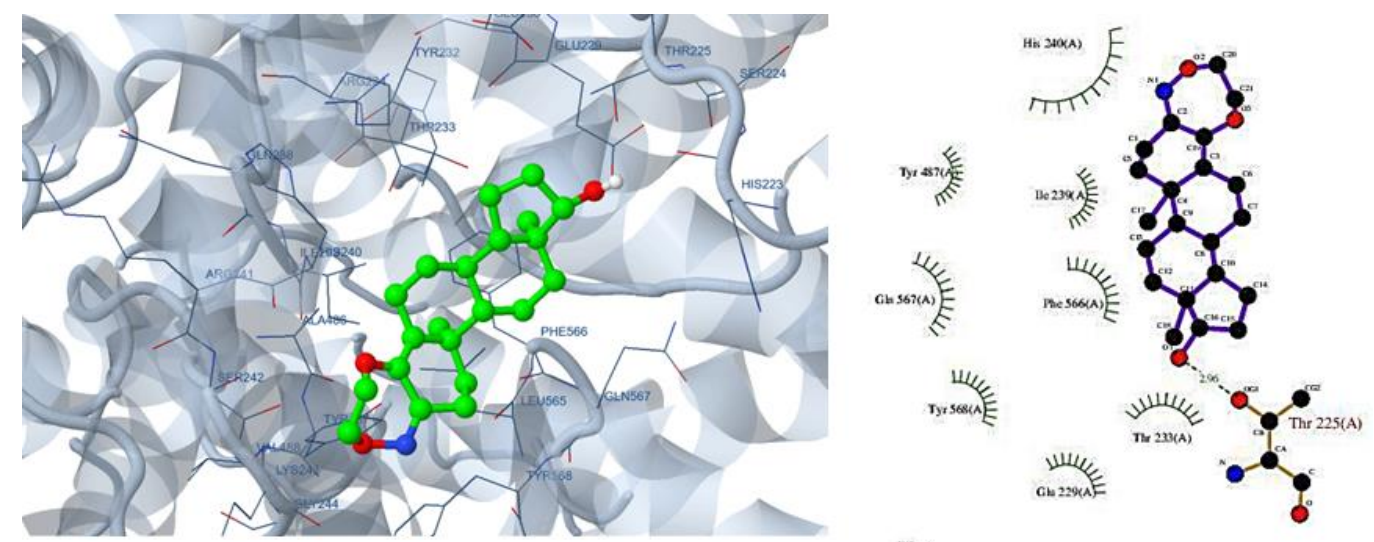

Key

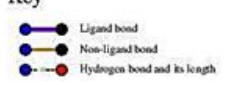

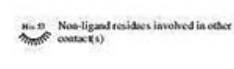

Figure 3. Interaction of compound 4 with 5i6z protein surface using Dockingserver software.
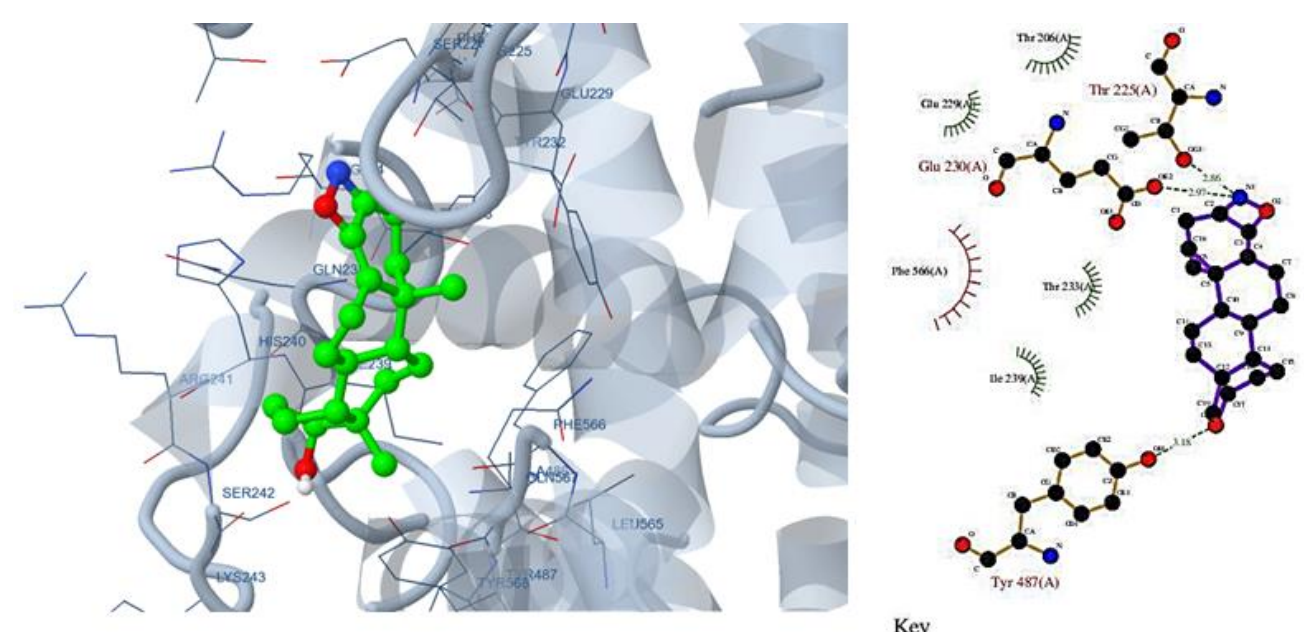

Key

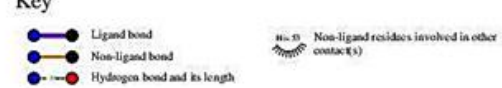

Figure 4. Interaction of compound 7 with either 5i6z protein surface using Dockingserver software.

The results showed differences in the type of amino acid residues involved in the interaction of fluoxetine and compound 4 and 7 with the $5 \mathrm{i} 6 \mathrm{z}$ protein surface (Table 1 and 2). These data could be due to the energy differences involved in the interaction of compounds 4 and 7 with the $5 \mathrm{i} 6 \mathrm{z}$ protein surface.

Table 1. Interaction of either compound 4 or fluoxetine with $5 \mathrm{i} 6 \mathrm{z}$ protein.

\begin{tabular}{l|l} 
Compound & Aminoacid residues \\
\hline \multirow{4}{*}{} & Thr $_{225}$ \\
& Glu $_{229}$ \\
& Thr $_{233}$ \\
& Ile $_{239}$ \\
& His $_{240}$ \\
& Tyr $_{487}$ \\
& Phe $_{566}$ \\
& Gln567 \\
& Tyr568 Thr $_{206}$ \\
& Asn $_{208}$ \\
& Hist $_{223}$ \\
& Thr $_{225}$ \\
& Glu $_{230}$ \\
& Ile $_{239}$ \\
& His $_{240}$ \\
& Tyr $_{487}$
\end{tabular}


Table 2. Interaction of either compound 7 or fluoxetine with $5 \mathrm{i} 6 \mathrm{z}$ protein.

\begin{tabular}{|c|c|}
\hline Compound & Aminoacid residues \\
\hline \multirow{8}{*}{7} & Thr $_{206}$ \\
\hline & $\mathrm{Thr}_{225}$ \\
\hline & Glu $_{229}$ \\
\hline & Glu $_{230}$ \\
\hline & $\mathrm{Thr}_{233}$ \\
\hline & $\mathrm{Ile}_{239}$ \\
\hline & $\mathrm{Tyr}_{487}$ \\
\hline & Phe $_{566}$ \\
\hline \multirow{11}{*}{ Fluoxetine } & $\mathrm{Phe}_{43}$ \\
\hline & Ala44 \\
\hline & Asp46 \\
\hline & $\mathrm{Val}_{113}$ \\
\hline & $\mathrm{Ile}_{116}$ \\
\hline & Ala 117 \\
\hline & Val $_{120}$ \\
\hline & Asp $_{121}$ \\
\hline & $\mathrm{Tyr}_{124}$ \\
\hline & $\operatorname{Ser}_{320}$ \\
\hline & $\mathrm{Leu}_{321}$ \\
\hline
\end{tabular}

To evaluate the energies involved in the interaction of either compounds $\mathbf{4}$ or $\mathbf{7}$ with $5 \mathrm{i} 6 \mathrm{z}$ protein surface was used the Dockingserver software (Table 3).

Table 3. Energy levels involved in the interaction of either compounds $\mathbf{4}$ or $\mathbf{7}$ or fluoxetine with 5i6z protein.

\begin{tabular}{l|l|l|l|l|l|l} 
Compound & $\begin{array}{l}\text { Est. Free } \\
\text { energy of } \\
\text { Binding } \\
(\text { Kcal/mol) }\end{array}$ & $\begin{array}{l}\text { Est. } \\
\text { Inhibition } \\
\text { Constant } \\
(\mathbf{K i}) \\
{[\boldsymbol{\mu M}]}\end{array}$ & $\begin{array}{l}\text { vdW } \\
\text { HBond } \\
\text { Desolv. } \\
\text { Energy } \\
(\text { Kcal/mol) }\end{array}$ & $\begin{array}{l}\text { Electrostatic } \\
\text { Energy } \\
(\text { Kcal/mol) }\end{array}$ & $\begin{array}{l}\text { Total Inter- } \\
\text { molec. } \\
\text { Energy } \\
(\text { Kcal/mol) }\end{array}$ & $\begin{array}{l}\text { Interact. } \\
\text { Surface }\end{array}$ \\
\hline $\mathbf{4}$ & -6.68 & 12.65 & -7.12 & 0.14 & -6.98 & 654.45 \\
\hline $\mathbf{7}$ & -5.87 & 50.01 & -6.19 & 0.02 & -6.17 & 582.38 \\
\hline Fluoxetine & -4.48 & 519.97 & -5.12 & 0.09 & -5.03 & 476.66
\end{tabular}

The results showed several differences in the energy levels involved in the interaction for either compounds 4, 7, and fluoxetine with 5i6z protein surface (Tables 3). Other data showed that the Ki value (inhibition constant) was lower for 4 compared with both compound 7 and fluoxetine; however, the Ki for 7 was higher in comparison with fluoxetine. All these data indicate that either compounds 4 or 7 could have a higher affinity for the 5i6z protein than fluoxetine, which could translate as a decrease in the serotonin transporter protein's biological activity.

\section{Conclusions}

In this investigation, the synthesis of two testosterone derivatives is reported using some chemical strategies. It's noteworthy that reagents used in this investigation no require special conditions. This study's theoretical study showed that either compounds 4 or 7 could be good serotonin transporters inhibitors.

\section{Funding}

This research received no external funding.

\section{Acknowledgments}

To Benjamin Valverde and Raquel Anzurez, for their unconditional support on this manuscript. 


\section{Conflicts of Interest}

The authors declare no conflict of interest.

\section{References}

1. Eildal, J.; Andersen, J.; Kristensen, A.; Jørgensen, A.; Bang, B.; Jørgensen, M.; Strømgaard, K. From the selective serotonin transporter inhibitor citalopram to the selective norepinephrine transporter inhibitor talopram: Synthesis and structure-activity relationship studies. Journal of Medicinal Chemistry 2008, 51, 3045-3048, https://doi.org/10.1021/jm701602g.

2. Zhang, H.; Xie, F.; Cheng, M.; Peng, F. Novel Meta-iodobenzylguanidine-Based Copper Thiosemicarbazide-1-guanidinomethylbenzyl Anticancer Compounds Targeting Norepinephrine Transporter in Neuroblastoma. Journal of Medicinal Chemistry 2019, 62, 6985-6991, https://doi.org/10.1021/acs.jmedchem.9b00386.

3. Sakamuri, S.; Enyedy, I.; Kozikowski, A.; Zaman, W.; Johnson, K.; Wang, S. Pharmacophore-based discovery, synthesis, and biological evaluation of 4-phenyl-1-arylalkyl piperidines as dopamine transporter inhibitors. Bioorganic and Medicinal Chemistry Letters 2001, 11, 495-500, https://doi.org/10.1016/S0960894X(00)00703-4.

4. Carlier, P.; Lo, M.; Lo, P.; Richelson, E.; Tatsumi, M.; Reynolds, I.; Sharma, T. Synthesis of a potent widespectrum serotonin-, norepinephrine-, dopamine-reuptake inhibitor (SNDRI) and a species-selective dopamine-reuptake inhibitor based on the gamma-amino alcohol functional group. Bioorganic and Medicinal Chemistry Letters 1998, 8, 487-492, https://doi.org/10.1016/S0960-894X(98)00062-6.

5. Zhou, J.; Kläß, T.; Zhang, A.; Johnson, K.; Wang, C.; Ye, Y.; Kozikowski, A. Synthesis and pharmacological evaluation of (Z)-9-(heteroarylmethylene)-7-azatricyclo [4.3. 1.03, 7] decanes: Thiophene analogues as potent norepinephrine transporter inhibitors. Bioorganic and Medicinal Chemistry Letters 2003, 13, 35653569, https://doi.org/10.1016/S0960-894X(03)00786-8.

6. Petersen, M.; Boye, S.; Nielsen, E.; Willumsen, J.; Sinning, S.; Wiborg, O.; Bols, M. Synthesis, inhibition and binding of simple non-nitrogen inhibitors of monoamine transporters. Bioorganic and Medicinal Chemistry 2007, 15, 4159-4174, https://doi.org/10.1016/j.bmc.2007.03.069.

7. Kozikowski, A.; Zhao, L.; Zhang, A.; Wang, C.; Flippen, J.; Johnson, K. Structural remodeling of cocaine: design and synthesis of trisubstituted cyclopropanes as selective serotonin reuptake inhibitors. ChemMedChem 2006, 1, 58-65.

8. Christensen, H.; Schjøth-Eskesen, C.; Jensen, M.; Sinning, S.; Jensen, H. Synthesis of 3, 7-Disubstituted Imipramines by Palladium-Catalysed Amination/Cyclisation and Evaluation of Their Inhibition of Monoamine Transporters. Chemistry-A European Journal 2011, 17, 10618-10627, https://doi.org/10.1002/chem.201100885.

9. Réau, M.; Langenfeld, F.; Zagury, J.; Montes, M. Predicting the affinity of Farnesoid X Receptor ligands through a hierarchical ranking protocol: a D3R Grand Challenge 2 case study. Journal of Computer-aided Molecular Design 2018, 32, 231-238, https://doi.org/10.1007/s10822-017-0063-0.

10. Penmatsa, A.; Wang, K.; Gouaux, E. X-ray structure of dopamine transporter elucidates antidepressant mechanism. Nature 2013, 503, 85-90, https://doi.org/10.1038/nature12533.

11. Coleman, J.; Green, E.; Gouaux, E. X-ray structures and mechanism of the human serotonin transporter. Nature 2016, 532, 334-339, https://doi.org/10.1038/nature17629.

12. Lauro, F.; Francisco, D.; Marcela, R.; Virginia, M.; Eduardo, P.; Maria, L.; Jhair, C. Preparation of a steroidoxazole-1, 2'-[1, 3] oxazete] derivative: biological and theoretical evaluation of its interaction with a kinase protein (CK2). SN Applied Sciences 2019, 1, https://doi.org/10.1007/s42452-019-0378-7.

13. Owens, M.; Knight, D.; Nemeroff, C. Second-generation SSRIs: human monoamine transporter binding profile of escitalopram and R-fluoxetine. Biological Psychiatry 2001, 50, 345-350, https://doi.org/10.1016/S0006-3223(01)01145-3.

14. Penmatsa, A.; Wang, K.; Gouaux, E. X-ray structures of Drosophila dopamine transporter in complex with nisoxetine and reboxetine. Nature Structural and Molecular Biology 2015, 22, 506-508, https://doi.org/10.1038/nsmb.3029.

15. Coleman, J.; Green, E.; Gouaux, E. X-ray structures and mechanism of the human serotonin transporter. Nature 2016, 532, 334-339, https://doi.org/10.1038/nature17629.

16. Lauro, F.; Francisco, D.; Marcela, R.; Virginia, M.; Eduardo, P.; Maria, L.; Jhair, C. Preparation of a steroidoxazole-1, 2'-[1,3] oxazete] derivative: biological and theoretical evaluation of its interaction with a kinase protein (CK2). SN Applied Sciences 2019, 1, https://doi.org/10.1007/s42452-019-0378-7.

17. Owens, M.; Knight, D.; Nemeroff, C. Second-generation SSRIs: human monoamine transporter binding profile of escitalopram and R-fluoxetine. Biological Psychiatry 2001, 50, 345-350, https://doi.org/10.1016/S0006-3223(01)01145-3. 
18. Chang, Y.; Liao, M.; Li, X. Reduction of liquid terminated-carboxyl fluoroelastomers using NaBH4/SmCl3. RSC Advances 2020, 10, 10932-10938, https://doi.org/10.1039/C9RA10069E.

19. Atassi, M.Z.; Rosenthal, A.F.; Vargas, L. Sterically selective reduction of protein carboxyl groups by disiamylborane or by 9-borabicyclo[3,3,1] nonane. Biochimica et Biophysica Acta (BBA) - Protein Structure 1973, 303, 379-384, https://doi.org/10.1016/0005-2795(73)90373-5.

20. Gribble, G.W. Sodium borohydride in carboxylic acid media: a phenomenal reduction system. Chemical Society Reviews 1998, 27, 395-404, https://doi.org/10.1039/A827395Z.

21. Ishizumi, K.; Koga, K.; Yamada, S. Chemistry of Sodium Borohydride and Diborane. IV. Reduction of Carboxylic Acids to Alcohols with Sodium Borohydride through Mixed Carbonic-Carboxylic Acid Anhydrides. Chemical \& Pharmaceutical Bulletin 1968, 16, 492-497, https://doi.org/10.1248/cpb.16.492.

22. Soai, K.; Ookawa, A. Mixed solvents containing methanol as useful reaction media for unique chemoselective reductions within lithium borohydride. The Journal of Organic Chemistry 1986, 51, 40004005, https://doi.org/10.1021/jo00371a017.

23. Falorni, M.; Porcheddu, A.; Taddei, M. Mild reduction of carboxylic acids to alcohols using cyanuric chloride and sodium borohydride. Tetrahedron Letters 1999, 40, 4395-4396, https://doi.org/10.1016/S00404039(99)00734-0.

24. Murray, R.W.; Jeyaraman, R.; Mohan, L. A new synthesis of nitro compounds using dimethyldioxirane. Tetrahedron Letters 1986, 27, 2335-2336, https://doi.org/10.1016/S0040-4039(00)84522-0.

25. Foroumadi, A.; Mansouri, S.; Kiani, Z.; Rahmani, A. Synthesis and in vitro antibacterial evaluation of N-[5(5-nitro-2-thienyl)-1,3,4-thiadiazole-2-yl] piperazinyl quinolones. European Journal of Medicinal Chemistry 2003, 38, 851-854, https://doi.org/10.1016/S0223-5234(03)00148-X.

26. Chauvière, G.; Bouteille, B.; Enanga, B.; de Albuquerque, C.; Croft, S.L.; Dumas, M.; Périé, J. Synthesis and biological activity of nitro heterocycles analogous to megazol, a trypanocidal lead. J Med Chem 2003, 46, 427-440, https://doi.org/10.1021/jm021030a.

27. Boswell, G.A., Jr. Reaction of nitrosyl fluoride and selected steroid enes. A new synthesis of delta-5-4-keto steroids. J Org Chem 1968, 33, 3699-3713, https://doi.org/10.1021/jo01274a005.

28. Cornelis, A.; Laszlo, P.; Pennetreau, P. Clay-supported reagents. 5. Nitration of estrone into 2-nitroestrone by clay-supported ferric nitrate. The Journal of Organic Chemistry 1983, 48, 4771-4772, https://doi.org/10.1021/jo00172a062.

29. Herrera, C.; Cortes, M.; Larrubia, M.; Domínguez, M.; Díaz, M.; Alemany, L. Dimethyl ether synthesis via methanol dehydration over Ta-supported catalysts. Applied Catalysis A: General 2019, 582, https://doi.org/10.1016/j.apcata.2019.05.022.

30. Chen, X.; Xiao, X.; Sun, H.; Li, Y.; Cao, H.; Zhang, X.; Lian, Z, Yang, S. Transition-Metal-Catalyzed Transformation of Sulfonates via S-O Bond Cleavage: Synthesis of Alkyl Aryl Ether and Diaryl Ether. Organic letters 2019, 21, 8879-8883, https://doi.org/10.1021/acs.orglett.9b02858.

31. Ma, X.; Song, Q. Tert-Butyl Nitrite Mediated Synthesis of Fluorinated O-Alkyloxime Ether Derivatives. Organic letters 2019, 21, 7375-7379, https://doi.org/10.1021/acs.orglett.9b02689.

32. Chavan, S.; Kadam, A.; Lasonkar, P.; Gonnade, R. Synthesis of 3-Azidopiperidine Skeleton Employing Ceric Ammonium Nitrate (CAN)-Mediated Regioselective Azidoalkoxylation of Enol Ether: Total Synthesis of D2 Receptor Agonist ( \pm )-Quinagolide. Organic letters 2018, 20, 7011-7014, https://doi.org/10.1021/acs.orglett.8b02900.

33. Figueroa-Valverde, L.; Rosas, M.; Lopez, M.; Diaz, F.; Mateu, V.; Garcimarrero, A.; Ortiz, Y. Synthesis of a New Dioxaspiro [bicyclo [3.3. 1] nonane-oxabicyclo [6.2. 0] deca-1 (10), 8-dien-4-one Derivative Using Some Chemical Strategies. Letters in Organic Chemistry 2020, 17, 393-402, https://doi.org/10.2174/1570178617666191116123359.

34. Guterres, H.; Im, W. Improving protein-ligand docking results with high-throughput molecular dynamics simulations. Journal of Chemical Information and Modeling 2020, 60, 2189-2198, https://doi.org/10.1021/acs.jcim.0c00057.

35. Liu, Y.; Grimm, M.; Dai, W,; Hou, M.; Xiao, Z.; Cao, Y. CB-Dock: a web server for cavity detection-guided protein-ligand blind docking. Acta Pharmacologica Sinica 2020, 41, 138-144, https://doi.org/10.1038/s41401-019-0228-6.

36. Shen, C.; Ding, J.; Wang, Z.; Cao, D.; Ding, X.; Hou, T. From machine learning to deep learning: Advances in scoring functions for protein-ligand docking. Wiley Interdisciplinary Reviews: Computational Molecular Science 2020, 10, https://doi.org/10.1002/wcms.1429. 